Portland State University

PDXScholar

8-2009

\title{
Fecal-Sac Ingestion by Spotted Towhees
}

Jenny E. McKay

Watershed Sciences Inc.

Michael T. Murphy

Portland State University, murphym@pdx.edu

Sarah Bartos Smith

Dartmouth College

Jennifer K. Richardson

Portland State University

Follow this and additional works at: https://pdxscholar.library.pdx.edu/bio_fac

Part of the Biology Commons, and the Ornithology Commons

Let us know how access to this document benefits you.

\section{Citation Details}

McKay, J. E., M. T. Murphy, S. Bartos Smith, and J. K. Richardson. 2009. Fecal sac ingestion by spotted towhees. Condor 111:503-510.

This Article is brought to you for free and open access. It has been accepted for inclusion in Biology Faculty Publications and Presentations by an authorized administrator of PDXScholar. Please contact us if we can make this document more accessible: pdxscholar@pdx.edu. 


\title{
FECAL-SAC INGESTION BY SPOTTED TOWHEES
}

\author{
Jenny E. McKay ${ }^{1}$, Michael T. Murphy ${ }^{2}$, Sarah Bartos Smith ${ }^{3}$, and Jennifer K. Richardson \\ Department of Biology, Portland State University, Portland, OR 97207
}

\begin{abstract}
Altricial nestlings encase excrement in fecal sacs that parents remove by either ingesting them or transporting them away from the nest. Ingestion may allow energetically or nutritionally deprived parents to recapture energy or nutrients that might be lost because of nestlings' inefficient digestion (the "parental-nutrition hypothesis"), but ingestion may also permit parents to avoid flights from the nest that interfere with parental care (e.g., brooding young; the "economic-disposal hypothesis"). We used a hypothetico-deductive approach to test the two hypotheses' ability to account for fecal-sac ingestion by the Spotted Towhee (Pipilo maculatus). We confirmed the parental-nutrition hypothesis' predictions that more fecal sacs should be ingested in years of food shortage (males only), late in the season when food supplies decline (both sexes), by parents that had the greatest difficulty raising young (i.e., underweight young), and that adults' body condition should vary directly with their rate of fecal-sac ingestion (females only). We rejected the economic-disposal hypothesis' prediction of a decline in fecal-sac ingestion with increasing brood size. The latter, plus the observation that nearly $40 \%$ of males ingest fecal sacs despite their spending virtually no time attending nests, suggests that fecal-sac ingestion is not a mechanism to avoid needless and time-consuming flights from the nest that interfere with parental care. Fecal-sac ingestion by Spotted Towhees is better interpreted as either a resource supplement to parents or as a mechanism to satiate hunger so that parents can maintain rates of feeding to dependent young.
\end{abstract}

Key words: coprophagy; economic-disposal hypothesis; fecal sacs; nest sanitation; parental behavior; parental-nutrition hypothesis; Pipilo maculatus; Spotted Towhee.

\section{Ingestión de Sacos Fecales en Pipilo maculatus}

Resumen. Los pichones nidícolas encapsulan sus excrementos en sacos fecales que sus padres remueven ya sea ingiriéndolos o transportándolos lejos del nido. La ingestión podría ayudar a que padres que están limitados energética o nutricionalmente recapturen energía o nutrientes que se perderían debido a la ineficiencia digestiva de los pichones (hipótesis de nutrición parental). Por otro lado, la ingestión también permitiría que los padres eviten dejar el nido, lo que interfiere con el cuidado parental (e.g. empollar las crías; hipótesis de disposición económica). Empleamos un enfoque hipotético-deductivo para poner a prueba la capacidad de las dos hipótesis de explicar la ingestión de sacos fecales en Pipilo maculatus. Confirmamos las predicciones de la hipótesis de nutrición parental, que sostiene que más sacos fecales deberían ingerirse (i) en años de escasez de alimento (sólo por los machos), (ii) en la parte final de la temporada cuando la abundancia de alimento disminuye (ambos sexos) y (iii) por parte de los padres con la mayor dificultad para criar los pichones (i.e., aquellos con pichones bajos de peso), y además que la condición corporal de los adultos debería variar directamente con su tasa de ingestión de sacos fecales (sólo en las hembras). Rechazamos la predicción de la hipótesis de disposición económica, que sostiene que existiría una disminución en la ingestión de sacos fecales al aumentar el tamaño de la nidada. Esto, sumado a la observación de que cerca del $40 \%$ de los machos ingieren sacos fecales a pesar de no invertir prácticamente nada de tiempo en el cuidado de los pichones en el nido, sugiere que la ingestión de sacos fecales no es un mecanismo para evitar vuelos desde el nido que son innecesarios, toman tiempo e interfieren con el cuidado parental. La ingestión de sacos fecales por parte de P. maculatus se interpreta mejor como un suplemento de recursos para los padres o como un mecanismo para mitigar el hambre, de modo que los padres puedan mantener las tasas de aprovisionamiento a los pichones que dependen de ellos para alimentarse.

\section{INTRODUCTION}

The rapid conversion of food into nestlings' tissue is one of several advantages of altricial development (Ricklefs and Starck 1998). However, the rapid processing of food results in abundant waste production, and — in altricial birds — nestlings package excreta in fecal sacs multiple times per hour for the entire nestling period (Herrick 1900, Blair and Tucker 1941, Tucker 1942, Weatherhead 1984). Fecal sacs permit efficient parental handling of wastes, lessen both fouling of the nest and exposure of nestlings to parasites and pathogens (Møller 1993; Lang 2002), and reduce odors that may attract predators

Manuscript received 29 October 2008; accepted 22 April 2009.

${ }^{1}$ Present address: Watershed Sciences Inc., 215 SE 9th Ave, Suite 106, Portland, OR 97214.

2E-mail: murphym@pdx.edu

${ }^{3}$ Present address: Environmental Studies, Dartmouth College, Hanover, NH 03755.

The Condor, Vol. 111, Number 3, pages 503-510. ISSN 0010-5422, electronic ISSN 1938-5422. ( 2009 by The Cooper Ornithological Society. All rights reserved. Please direct all requests for permission to photocopy or reproduce article content through the University of California Press's Rights and Permissions website, http://www.ucpressjournals.com/ reprintInfo.asp. DOI: $10.1525 /$ cond.2009.080065 
(Petit et al. 1989). Nest sanitation is thus an important part of parental care, yet it has received far less attention than either parental feeding or nest defense behavior.

Fecal-sac removal occurs either by ingestion or transport and deposition away from the nest, but the basis upon which parents make the decision to ingest or transport is unclear. Fecal-sac consumption generally declines steadily throughout the nestling period (e.g., Blair and Tucker 1941, Hurd et al. 1991). One hypothesis to explain this pattern is that parents ingest fecal sacs to recapture energy or nutrients that would otherwise be lost because of inefficient digestion by young nestlings (the "parental-nutrition hypothesis" [PNH; Morton 1979, McGowan 1995] or "recycling hypothesis" [Dell'Omo et al. 1998]). Recapture of energy, nutrients, or water, contained in nestling excreta, especially in times of food or water shortage, might supplement the adults' metabolic needs and allow them to shunt a higher proportion of captured prey to developing young. Morton (1979) showed that fecal sacs contain usable protein, calories, and substantial amounts of water, but the analyses of Hurd et al. (1991) indicated little change in energy content (therefore digestive efficiency) with nestlings' age. The latter authors therefore rejected the hypothesis that the decline in fecal-sac consumption with nestling age is driven mainly by declining energetic benefits and questioned the parental-nutrition hypothesis' premise that fecal sacs are a potential resource to parents.

Nest sanitation, while necessary, is potentially costly, and decisions to ingest or transport fecal sacs may represent a compromise between competing demands on parental time and behavior. Ingestion may introduce pathogens or parasites into adults' digestive tracts, and fecal sacs may occupy space that could otherwise be filled with food (Hurd et al. 1991). But transport of fecal sacs also requires time and energy, and transport away from the nest may prevent parents from performing other activities such as brooding or nest attendance. The decision to consume fecal sacs might thus represent a tactic to permit parents to reduce time spent on disposal and increase time allocated to other activities (the "economic-disposal hypothesis" [EDH]; Hurd et al. 1991).
Previous attempts to explain fecal-sac ingestion and test the PNH and EDH (Hurd et al. 1991, McGown 1995) used temporal analyses of fecal-sac ingestion as nestlings aged. Here, we take a different approach and focus instead on a three-day period in the latter half of the nestling period of the Spotted Towhee (Pipilo maculatus) when daily growth of nestlings (Barbour 1950) and parental feeding rates (McKay 2008) are high. We presuppose that parents are challenged to meet the competing demands of self-maintenance and parental care and use a hypothetico-deductive approach to test predictions of the two hypotheses to identify the basis for fecal-sac ingestion by towhees.

Towhees breed as putatively monogamous pairs, attempt to raise at least two broods per year (Greenlaw 1996), and both parents participate in the care of young. Females are, however, more energetically stressed and face greater constraints on their time than do males (see below). The PNH and EDH therefore both predict that females (the more energetically stressed and time-constrained sex) should consume more fecal sacs. The EDH predicts that fecal-sac ingestion occurs only to permit parents to perform behaviors that compete with the transport of fecal sacs. But brooding females cannot feed themselves, and therefore both hypotheses also predict that fecal-sac ingestion will increase with time spent brooding. Other tests, however, yield distinctly different predictions (Table 1).

For instance, if fecal sacs are a source of energy or nutrients for parents, as assumed only by the $\mathrm{PNH}$, we predicted greater fecal-sac ingestion when parents were energetically stressed: during periods of low food availability, by parents tending the largest broods, and by parents otherwise having difficulty raising young (as evidenced by underweight young). Moreover, the benefit of fecal-sac ingestion should be apparent as higher body condition among parents that consume the most fecal sacs (Table 1).

In contrast, the EDH assumes that fecal sacs have no nutritive or energetic value and that ingestion is unrelated to the parents' energetic state. Hence, the rate of fecal-sac ingestion should be independent of food availability, the ability of the parents to raise heavy young, or parental condition. On the

TABLE 1. A summary of the predicted patterns of fecal-sac ingestion by the parental-nutrition and economic-disposal hypotheses.

\begin{tabular}{|c|c|c|}
\hline \multirow[b]{2}{*}{ Comparison } & \multicolumn{2}{|c|}{ Predicted pattern of fecal-sac ingestion } \\
\hline & Parental nutrition & Economic disposal \\
\hline Sex & Female $>$ male & Female $>$ male \\
\hline Brooding time & Increase & Increase \\
\hline Food availability & $\begin{array}{l}\text { Greater in year of low food availability, } \\
\text { and late in year as food declines }\end{array}$ & $\begin{array}{l}\text { Unrelated to yearly or seasonal } \\
\text { differences in food availability }\end{array}$ \\
\hline Offspring quality & Most common in broods with light young & No relationship with nestling weight \\
\hline Brood size & Increase with brood size & Decline with brood size \\
\hline Parental condition & Increase with fecal-sac ingestion & Independent of fecal-sac ingestion \\
\hline
\end{tabular}


other hand, fecal-sac ingestion should decline with increasing brood size because large broods require little brooding (i.e., less heat is lost from large broods; Dunn 1976) and the frequent flights to feed the large number of young provide opportunities to dispose of fecal sacs (Table 1).

\section{METHODS}

\section{STUDY SITE AND SPECIES}

We collected parental behavior data on towhees nesting in six urban parks in southwestern Portland, Oregon $\left(45^{\circ} 31^{\prime} \mathrm{N} 122^{\circ}\right.$ $40^{\prime} \mathrm{W}$ ), during 2005 and 2006 . The parks are all approximately 60 years old, contain an abundant shrubby understory, and the dominant tree species at all sites are bigleaf maple (Acer macrophyllum) and Douglas-fir (Pseudotsuga menziesii).

Portland's climate is characterized by abundant winter rainfall (November through March) and an annual summer drought that begins by mid to late June. The 2006 breeding season experienced below-average precipitation but aboveaverage air temperatures, whereas precipitation and air temperature during the 2005 breeding season both fell within the normal range of variation (McKay 2008). The growth of populations of invertebrates, the primary food of nestling towhees (Greenlaw 1978), is negatively affected by drought (Tanaka and Tanaka 1982, Murphy 1986, Blancher and Robertson 1987, Grant et al. 2000), so we assumed that 2006 and the latter half of both breeding seasons were periods of relatively low food availability. In support of our assumptions, the rates of parental feeding and delivery of invertebrate prey were both significantly lower in 2006 than in 2005 (McKay 2008). Similarly, the parental feeding rate and body mass of young in large broods (four young) declined seasonally, whereas deliveries of plant material increased (McKay 2008).

At Portland, the towhee's breeding season extends from late March to early August. Females build nests, incubate eggs and brood young without male assistance, but both sexes contribute to the feeding of young, their defense, and nest sanitation. Most females lay clutches of three eggs (range 2-5) and take roughly two weeks to complete incubation (12-14 days). Nestlings fledge at 9 days of age (hatching $=1$ ) if disturbed, but most do not fledge until they are 10 to 11 days old (Greenlaw 1996; Bartos Smith, unpubl. data).

\section{FIELD METHODS}

We monitored nests every 2 to 3 days to document laying dates, clutch size, number of hatchlings, and number of young to fledge. The age of young found after hatching was determined within the first 2 days of hatching from measurements of body size and plumage development of known-age individuals (Barbour 1950). Young were banded (one U.S. Fish and Wildlife Service band and three plastic colored bands) and had their mass (nearest $0.1 \mathrm{~g}$; Pesola scale) and right tarsus length (nearest $0.1 \mathrm{~mm}$; dial calipers) measured when the oldest nestling was 6 or 7 days old. Fledging success equaled the number of nestlings alive on day 8 , just prior to fledging.

We captured and banded adults by using mist nets and a taxidermic mount accompanied by playback of conspecific song (most males) or at nests during flights to feed young (both sexes). Adults were sexed by their dichromatic plumage and classified as second year (SY; first potential breeding season) or after second year (ASY; all later breeding seasons) by other plumage characters (Pyle 1997). We then measured (body mass, wing chord, tarsus, and tail lengths) and marked each bird with a unique combination of aluminum and color bands.

\section{BEHAVIORAL OBSERVATIONS}

We placed video cameras (Sony Hi8 digital camera recorders) in camouflaged ammunition boxes mounted on tripods 0.5 $1.5 \mathrm{~m}$ from nests. Recordings of the 5- to 7-day-old nestlings were made between 07:00 and 13:00 Pacific Standard Time for $70 \mathrm{~min}$. Vegetation was sometimes moved temporarily to improve the camera's view of the nest, but this had no influence on the nest's probability of fledging young (McKay 2008). We excluded the first $10 \mathrm{~min}$ of observation to permit the adults to return to their normal behavior; all observations were therefore based on a 1-hr recording. Time of day and brood size were recorded at each observation, and rainfall and minimum and maximum air temperature for the day on which observations were made were obtained from the Oregon Climate Service (www.ocs.oregonstate.edu). Films were later viewed (all by JEM) on a $48 \times 64-\mathrm{cm}$ television monitor to document (1) feeding rate (number of nest visits in which young were fed), (2) rate of nonfeeding visits, (3) fecal-sac-ingestion rate (number eaten per hour), (4) fecal-sac-transport rate (number removed but not eaten per hour), (5) total time spent brooding young, and (6) nest attendance (time spent at the nest without brooding young). To permit adults to complete feeding or nest sanitation we required that a $30-\mathrm{sec}$ period elapse between a towhee's arrival at a nest before recording nest attendance. With the exception of time spent brooding, all data were recorded separately by sex, then combined for some analyses.

\section{STATISTICAL ANALYSES}

We observed over half the females at more than one nest, but we used one randomly chosen nest for all females in our analyses. Feeding rate and nest-sanitation behaviors (fecal-sac ingestion and transport) were divided by brood size; given that they were recorded over one hour, behaviors are expressed as per capita rates per hour unless otherwise stated. To examine nest-sanitation behavior further, we also analyzed the proportion of total instances of nest sanitation that were ingestions (ingestion/[ingestion + transport). We compared male and female nest attendance, feeding rate, fecal-sac ingestion and transport, and the proportion of fecal-sac removals that were 
ingestions, as well as annual comparisons of parental behaviors and adult and nestling mass, with two-sample $t$-tests.

We used Pearson product-moment correlation $(r)$ to test for seasonal shifts in nest-sanitation behaviors, and for a relationship between fecal-sac ingestion and time spent brooding. We also employed forward-selection stepwise multiple regression to test for the predicted association between fecalsac ingestion and brooding time, while testing for possible confounding effects of other variables that included year, date, time of day, minimum air temperature on the date of observation, brood size, nestling age, and females' feeding rate. The partner's feeding rate and rate of total fecal-sac removal (ingestion + transport) were also included to account for possible influences of the partner's behavior on the rate of fecal-sac ingestion. To test the PNH's prediction that parents having difficulty raising young ingest the greatest number of fecal sacs, we examined nestlings' average mass at banding (6-7 days of age) in relation to the pair's rate of fecal-sac ingestion, along with other possible influences on nestling mass by using forward-selection stepwise regression. The independent variables for this analysis included year, date of measurement, nestling age, brood size, and the other parental behaviors previously described. We used analysis of variance to compare feeding rate and time spent brooding against brood size and to test the EDH's prediction that fecal-sac ingestion should be independent of brood size (because of the opportunity to carry fecal sacs away due to the large number of feeding trips required to feed large broods). Finally, we tested the PNH's prediction that adults' body condition should vary positively with fecal-sac consumption (= ingestion). We assessed condition (sexes examined separately) by including the significant morphological predictors of body mass in a stepwise regression along with total fecal-sac consumption and other factors that might generate variation in adult mass (i.e., year, date, brood size, and other parental behaviors).

Proportions were arcsine transformed, and several variables were $\log _{10}$ transformed to comply with assumptions of normality. Results are reported as means \pm SD and sample sizes $(n)$. Analyses were conducted with Statistix 8.0 (Analytical Software 2003) and SPSS (2002).

\section{RESULTS}

\section{COMPARISONS OF THE SEXES}

Females spent more than three times as much time attending to nests as did males (Table 2). Brooding young, which encompassed nearly one-third of each hour $(\bar{x}=19.6 \pm 18.60$ $\min \mathrm{hr}^{-1}, n=100$ ), was also performed only by females. The total number of trips to the nest and number of feeding trips were roughly $50 \%$ and $33 \%$, respectively, higher in females than in males (Table 2). After controlling for differences in body size (tarsus length entered into the regression to control for size differences between the sexes; regression coefficient $[b]=0.672, P=0.001)$ and date of weighing $(b=-0.015$, $P=0.050$ ), we found that males were heavier than females $\left(b=-1.429, P=0.001 ; R^{2}\right.$ of the 3 -variable model $=0.243$ ). Females thus had less time available to feed themselves, made more flights, and were in poorer body condition (i.e., relatively lighter). And as predicted by both hypotheses, the rate of females' fecal-sac ingestion was more than twice that of males (Table 2). The sexes' rate of fecal-sac transport did not differ, and therefore the proportion of total fecal-sac removals that were ingestions was also significantly higher in females (Table 2).

\section{ANNUAL AND SEASONAL VARIATION}

Differences in weather and parental behaviors suggested that 2006 was a poorer year for towhees than 2005 , and, in agreement, males' feeding rate and body mass of adult males and nestlings were lower in 2006 (Table 3). On the other hand, adult females' body mass and feeding rate in the two years did not differ (Table 3). The PNH predicted greater fecal-sac ingestion in 2006, and, as predicted, per capita male fecalsac ingestion was marginally higher and the proportion of fecal sacs ingested was significantly higher in 2006. Females

TABLE 2. Comparison by sex of parental behaviors of Spotted Towhees nesting in Portland, Oregon, parks and green spaces.

\begin{tabular}{|c|c|c|c|}
\hline Behavior $^{\mathrm{a}}$ & $\begin{array}{l}\text { Female } \\
\bar{x} \pm \text { SD }\end{array}$ & $\begin{array}{c}\text { Male } \\
\bar{x} \pm \mathrm{SD}\end{array}$ & $t(P)$ \\
\hline Nest attendance (min per hr) & $2.53 \pm 3.62$ & $0.79 \pm 2.03$ & $4.31(0.000)$ \\
\hline Trips (total) to nest (trips per hr) & $5.90 \pm 3.40$ & $3.89 \pm 2.90$ & $5.09(0.000)$ \\
\hline Feeding trips (trips per hr) & $5.01 \pm 3.69$ & $3.79 \pm 2.89$ & $3.10(0.003)$ \\
\hline Fecal-sac pickups per nestling per hr & $0.32 \pm 0.42$ & $0.27 \pm 0.35$ & $1.09(0.279)$ \\
\hline Fecal-sac ingestions per nestling per hr & $0.50 \pm 0.46$ & $0.23 \pm 0.35$ & $4.88(0.000)$ \\
\hline Fecal-sac ingestions (proportion of total) & $0.60 \pm 0.40$ & $0.43 \pm 0.44$ & $2.48(0.016)$ \\
\hline
\end{tabular}

a Sample size equals 100 for all except fecal-sac ingestions (proportion of total), for which $n=60$ (because of lack of fecal-sac removals by some pairs, precluding calculation of a proportion) 
TABLE 3. Comparison by year of parental behaviors and adult and nestling body mass of Spotted Towhees in Portland, Oregon.

\begin{tabular}{|c|c|c|c|}
\hline Trait & $\begin{array}{c}2005 \\
\bar{x} \pm \mathrm{SD}(n)\end{array}$ & $\begin{array}{c}2006 \\
\bar{x} \pm \operatorname{SD}(n)\end{array}$ & $t(P)$ \\
\hline Male mass $(\mathrm{g})^{\mathrm{a}}$ & $41.5 \pm 2.8$ & $40.1 \pm 2.3$ & $2.41(0.018)$ \\
\hline Female mass $(\mathrm{g})^{\mathrm{b}}$ & $38.8 \pm 2.0$ & $38.5 \pm 2.7$ & $0.47(0.637)$ \\
\hline Average nestling mass $(\mathrm{g})^{\mathrm{c}}$ & $25.1 \pm 2.5$ & $23.3 \pm 2.3$ & $3.28(0.002)$ \\
\hline Per capita male feeding rate per $\mathrm{hr}^{\mathrm{d}}$ & $1.6 \pm 1.04$ & $1.1 \pm 0.80$ & $2.20(0.030)$ \\
\hline Per capita female feeding rate per $\mathrm{hr}^{\mathrm{d}}$ & $1.9 \pm 1.43$ & $1.6 \pm 1.25$ & $0.97(0.334)$ \\
\hline Per capita male fecal-sac ingestions per $\mathrm{hr}^{\mathrm{d}}$ & $0.17 \pm 0.321$ & $0.29 \pm 0.370$ & $1.77(0.079)$ \\
\hline Per capita female fecal-sac ingestions per hr) ${ }^{\mathrm{d}}$ & $0.52 \pm 0.516$ & $0.48 \pm 0.400$ & $0.53(0.599)$ \\
\hline Pair fecal-sac ingestions (proportion of total) ${ }^{\mathrm{d}}$ & $0.48 \pm 0.34$ & $0.66 \pm 0.39$ & $2.32(0.022)$ \\
\hline Male fecal-sac ingestions (proportion of total) ${ }^{\mathrm{d}}$ & $0.28 \pm 0.38$ & $0.62 \pm 0.45$ & $3.28(0.002)$ \\
\hline Female fecal-sac ingestions (proportion of total) ${ }^{\mathrm{d}}$ & $0.57 \pm 0.38$ & $0.64 \pm 0.42$ & $0.80(0.428)$ \\
\hline
\end{tabular}

${ }^{\mathrm{a}}$ Sample sizes $=44$ (2005) and 37 (2006).

${ }^{\mathrm{b}}$ Sample sizes $=39(2005)$ and $37(2006)$.

${ }^{\mathrm{c}}$ Sample sizes $=43(2005)$ and $39(2006)$.

${ }^{\mathrm{d}}$ Sample sizes $=53(2005)$ and $47(2006)$.

exhibited no annual difference in either measure of fecal-sac ingestion.

Food availability presumably declined through the season with the onset of summer drought, and, as noted above, we detected seasonal declines in total feeding rate and body mass of young in large broods. Total fecal-sac production also declined with date $(r=-0.204, n=100, P=0.042)$, indicating that nestlings were fed less. The PNH thus predicted a seasonal increase in fecal-sac ingestion, whereas the EDH predicted no relationship between fecal-sac ingestion and date.

Fecal-sac transport declined seasonally in females $(r=$ $-0.250, n=100, P=0.007)$ and males $(r=-0.199, n=100$, $P=0.047)$, but fecal-sac ingestion was independent of date in both sexes (females: $r=0.125, n=100, P=0.216$; males: $r=0.047, n=100, P=0.640)$. However, when examined as the proportion of total fecal-sac removals that were ingestions, ingestion increased seasonally in both females $(r=0.268, n=$ $89, P=0.018)$ and males $(r=0.232, n=69, P=0.056$; sample size reduced because of the absence of fecal-sac removals by some individuals, precluding calculation of proportions). We also made paired comparisons of the proportion of fecal-sac removals that were ingestions between first and later nests of pairs $\left(t_{79}=4.35, P<0.001\right)$, females $\left(t_{75}=3.40, P=0.014\right)$ and males $\left(t_{57}=2.59, P=0.014\right)$. In all cases, the same pairs and individuals ingested a higher proportion of fecal sacs at later nests.

Univariate comparisons showed that females' fecal-sac ingestion was independent of time spent brooding young ( $r=$ $0.089, n=100, P=0.377$ ), but stepwise regression of females' fecal-sac-ingestion rates yielded a positive relationship between fecal-sac ingestion and time spent brooding $(b=0.006$, $P=0.012)$ after we accounted for positive relationships between females' fecal-sac ingestion and both feeding rate $(b=$ $0.151, P<0.001)$ and date of observation $(b=0.005, P=0.016$; $\left.R^{2}=0.180, P<0.001\right)$. The rate of females' fecal-sac ingestion thus increased with time spent brooding, as predicted by both the PNH and EDH, but also with date, as predicted by the PNH. An identical analysis of males indicated that fecal-sac ingestion increased when males fed young at high rates $(b=$ $0.089, P=0.016)$ but that fewer fecal sacs were ingested late in the day $(b=-0.054, P=0.036)$ and as nestlings aged $(b=$ $-0.161, P=0.011 ; R^{2}$ of 3-variable model $=0.125$ ).

\section{NESTLING QUALITY, BROOD SIZE, AND FECAL-SAC INGESTION}

The PNH predicted that fecal-sac ingestion would be most common among parents that fed underweight young. Our analysis of average body mass of nestlings that survived to be weighed ( $n=82$ broods) showed that the heaviest nestlings were older (standardized regression coefficient $[b]=1.372$, $P=0.013)$, were in small broods $(b=-0.613, P=0.055)$, were raised in $2005(b=-1.314, P=0.014)$, and, as predicted by the PNH, were raised by parents that ingested the fewest fecal sacs $\left(b=-0.929, P=0.040 ; R^{2}\right.$ of 4 -variable model $\left.=0.245\right)$.

As expected, the number of feeding trips increased with brood size (analysis of variance: $F_{3,96}=12.27, P<0.001$; Fig. 1a), while time spent brooding declined $\left(F_{3,96}=13.27, P<\right.$ 0.001 ; Fig. 1b). Contrary to predictions of the EDH, but consistent with the $\mathrm{PNH}$, total fecal-sac ingestion increased with brood size $\left(F_{3,96}=2.65, P=0.053\right.$; Fig. $\left.1 \mathrm{c}\right)$, owing primarily to increased rates of ingestion by females $(r=0.224, P=0.025)$ but not by males $(r=0.155, P=0.126)$.

\section{PARENTAL CONDITION AND FECAL-SAC INGESTION}

Females' body mass correlated positively with wing chord and tarsus length, and after both were accounted for (i.e., body size), females' mass declined as feeding rate and time spent in nest attendance increased, late in the season, but increased with fecal-sac ingestion (Table 4). A similar analysis for males 

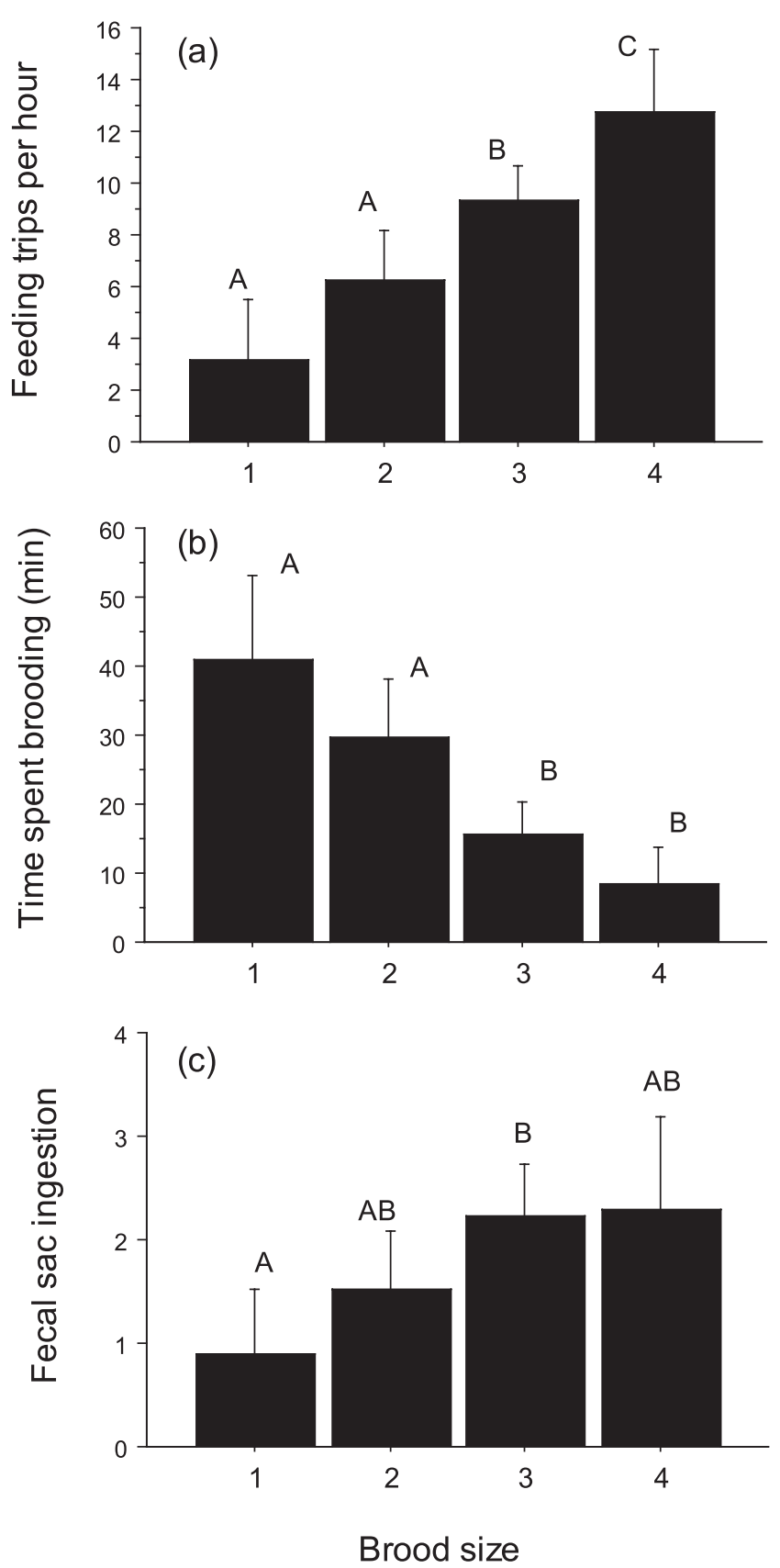

FIGURE 1. Variation in the (a) number of feeding trips per hour made to nests by both parents, (b) amount of time per hour females spent brooding young, and (c) number of fecal sacs ingested by the pair per hour in relation to brood size. Error bars are $95 \%$ confidence intervals. Letters adjacent to error bars indicate statistical differences between groups in post hoc tests (Tukey's test) based on analysis of variance. Brood sizes with shared letters did not differ statistically from one another.

showed that body mass declined with date $(P=0.018)$, was lower in $2006(P=0.036)$, and was greater in birds with wide bills $(P=0.026)$, but was independent of fecal-sac ingestion and other parental behaviors (results not shown).
TABLE 4. Results of the stepwise linear regression of female towhees' body mass in relation to structural measures of size, date of observation, and parental behaviors. ${ }^{\mathrm{a}}$

\begin{tabular}{lrc}
\hline \hline Variable & \multicolumn{1}{c}{$b$} & $t(P)$ \\
\hline Wing chord & 0.259 & $2.86(0.006)$ \\
Tarsus length & 0.794 & $2.79(0.007)$ \\
Feeding rate & -0.612 & $3.35(0.001)$ \\
Nest attendance & -0.604 & $2.67(0.010)$ \\
Fecal-sac ingestion & 1.364 & $2.51(0.015)$ \\
Date & -0.021 & $2.06(0.044)$ \\
\hline a $R^{2}=0.405, n=75, P<0.001$ &
\end{tabular}

\section{DISCUSSION}

Ingestion of feces is common among herbivorous animals (reviewed by Lombardo 2008) but is largely restricted to juveniles that must be inoculated with endosymbionts to digest the cellulosic material that constitutes their diets. Most nonherbivorous vertebrates do not regularly ingest feces, but the behavior is nonetheless known to occur when adults are nutritionally deprived (Dyer 1998) or face restricted food intake (Kenagy et al. 1999). Parental ingestion of fecal sacs is, to our knowledge, universal among passerine birds (Herrick 1900, Blair and Tucker 1941, Tucker 1942), and the PNH is the most commonly invoked explanation for its occurrence (Morton 1979, McGown 1995). Our tests of that hypothesis and its main alternative, the EDH, yielded a few equivocal results but, when taken as a whole, produced stronger support for the hypothesis that Spotted Towhees ingest fecal sacs to offset shortfalls in food intake. Brood-parasitic female Brown-headed Cowbirds (Molothrus ater) may consume fecal sacs of their hosts' nestlings (Stake and Cavanaugh 2001), and among cooperative breeders helpers may consume fecal sacs of nestlings they attend (McGowan 1995). These observations are also consistent with the proposition that fecal sacs contain usable energy or nutrients because in neither case are individuals constrained by the need to perform other parental behaviors.

Part of the difficulty of identifying the basis for fecal-sac ingestion was the development of tests that unambiguously excluded one or the other hypothesis. Two examples are the comparison of fecal-sac ingestion by sex and the relationship between time spent brooding and rate of fecal-sac ingestion (Table 1). Females were in poorer body condition and devoted more time to parental care than did males, therefore both hypotheses predicted greater fecal-sac ingestion by females, a hypothesis confirmed in this study. Likewise, the underlying premise of the EDH is that parents ingest fecal sacs to avoid temporal costs of fecalsac transport so that other behaviors, namely, brooding young, can be performed. However, brooding females cannot feed, therefore both hypotheses predict that fecal-sac ingestion and time spent brooding will correlate positively. After controlling 
for confounding effects of feeding rate and date of observation, we in fact detected the predicted increase in fecal-sac ingestion as time spent brooding increased (Table 1).

Results of the remaining tests, however, lent little support to the EDH and mostly confirmed predictions of the PNH (Table 1). Much evidence suggested that food was less abundant in 2006. For instance, total feeding rate, males' feeding rate, and deliveries of invertebrate prey to nestlings were all lower in 2006 (McKay 2008, this study), as were nestlings' body mass (this study) and the pickup and transport of fecal sacs from the nest $(P=0.004$ after correction for the effects of the seasonal decline of fecal-sac removal). Lower body mass of adult males in 2006, despite the reduced rate at which males fed young (Table 3 ), also strongly suggested that less food was available in 2006. The PNH thus predicted greater fecal-sac ingestion in 2006, which we confirmed in males but not in females. The equal rates of females' fecal-sac ingestion in 2005 and 2006 are possibly explained by females' consistently high effort while brooding and feeding young (Table 2). Females possibly approached the maximum parental effort and maximum rate of fecal-sac ingestion in both years, and if so, would gain no additional benefits by ingesting more fecal sacs in the year of lower food availability. The amount of energy or nutrients that can be extracted from fecal sacs may be limited, and we suggest that in both years female towhees probably approached these limits. Indeed, the measure of females' body condition, although it increased with the rate of fecal sac ingestion (Table 4), tended to reach an asymptote at high rates (Fig. 2).

Seasonal declines in parental feeding rates, adult body mass, body mass of young in large broods, and total fecalsac production (McKay 2008; this study) all suggested that food availability declined seasonally as the normal summer

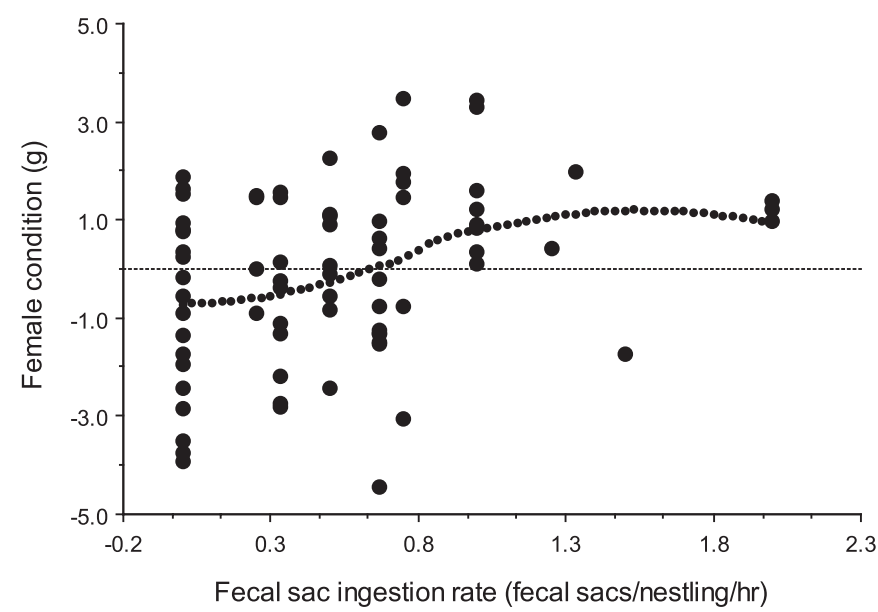

FIGURE 2. A LOESS plot of females' condition in relation to rate of fecal-sac ingestion. Condition is expressed as residual mass derived from a regression that removed the effects of size (wing chord and tarsus length), date of measurement, females' feeding rate, and time spent in nest attendance. The LOESS analysis accounted for $12.5 \%$ of the variation in females' condition. droughts commenced. The PNH predicted increased fecal-sac ingestion when food was limited, and, in agreement with this prediction, we showed that the proportion of fecal sacs ingested increased with date in both sexes. Moreover, after controlling for covariation of females' fecal-sac ingestion with feeding rate and time spent brooding young, we found that the absolute rate of fecal-sac ingestion also increased seasonally. Therefore we rejected the EDH's prediction of no seasonal change in fecalsac ingestion as food supplies decline seasonally.

The EDH also predicted no relationship between fecalsac ingestion and nestling weight, but our evidence confirmed the PNH's prediction that parents having the greatest difficulty raising young (i.e., those with light young) consume the most fecal sacs (Table 1). Because feeding visits (and departures from the nest) increased with brood size (Fig. 1a), the EDH also predicted that fecal-sac ingestion should decline with increasing brood size (Table 1) because the parents of large broods have the most opportunities to transport fecal sacs away from the nest. In direct conflict with this expectation, but consistent with the PNH, we observed an increase in fecal-sac ingestion with brood size (Fig. 1c). To this we add that the positive correlation of fecal-sac ingestion with feeding rate by both sexes (see above) is inconsistent with the EDH because, again, high feeding rates permit transport of fecal sacs from the nest. Dell'Omo et al. (1998) detected a similar pattern of fecal-sac consumption with brood size in the Common Swift (Apus apus) and argued that parents consume fecal sacs to recycle energy, nutrients, or possibly water contained in the excreta. If this is the case, benefits to parents should be evident, and, as predicted by the PNH, adult females' body condition increased with fecalsac ingestion (Table 4 and Fig. 2).

Although most patterns of fecal-sac ingestion are consistent with the PNH (Table 1), it does not follow that constraints on the care of young have no bearing on the ingestion of fecal sacs. For instance, fecal-sac ingestion in the first few days after hatching, when nestlings lack the ability to thermoregulate, may be influenced by the need to avoid flights from the nest to permit females to brood young. The positive correlation between ingestion rates and time spent brooding lends some support to the EDH. But, as described above, brooding time reduces the time available for a female to feed, and the $\mathrm{PNH}$ also predicts an increase in fecal-sac ingestion with time spent brooding. The assumption that adults consume fecal sacs to facilitate nest attendance is not unreasonable: generally, trips to the nest that were followed by brooding young also involved a period of nest attendance during which the female seemed to wait for the young to defecate. And indeed, the time that females spent in nest attendance was correlated with the rate of fecal-sac ingestion $(r=0.340, P<0.001)$. Fecal-sac ingestion under these circumstances conforms to expectations of the EDH because the female avoided a timeconsuming flight from the nest. However, the total time that females spent in nest attendance was short $(2.5 \pm 3.62 \mathrm{~min}$ 
$\mathrm{hr}^{-1}, n=100$ ), and therefore the trade-off between nest attendance and fecal-sac ingestion seems at best to account only secondarily for patterns of fecal-sac ingestion, at least during the latter half of the nestling period. Possibly the most convincing argument against the EDH is the fact that males consumed fecal sacs. Male towhees did not brood young and on average spent $<1 \mathrm{~min} \mathrm{hr}^{-1}$ in nest attendance. Consequently, they faced no potential trade-off between the need to attend to the nest or transport fecal sacs. Yet nearly $40 \%$ of males (37 of 100) consumed fecal sacs. This, combined with the rejection of the EDH's prediction of a decline in fecal-sac ingestion with increasing brood size (and feeding rate), are compelling evidence that argue for a rejection of the hypothesis that fecalsac ingestion allows parents to avoid needless flights from the nest so that they can perform other behaviors.

Nonetheless, given that we lack information on the energetic or nutritional content of towhees' fecal sacs, we acknowledge the possibility that fecal-sac consumption carries no metabolic benefit. Instead, parents may simply consume fecal sacs as a proximate mechanism to suppress hunger to enable them to maintain food deliveries at high rates. "Parental satiation," rather than "parental nutrition," might then best account for fecal-sac ingestion, with the ultimate outcome being the maintenance of a high parental feeding effort. Definitive tests of the parental-nutrition, parental-satiation, and economicdisposal hypotheses will require that the nutritional value of fecal sacs be quantified (see Morton 1979, Hurd et al. 1991) and that food be provided experimentally to determine if supplemented pairs replace fecal-sac ingestion with food intake. From our data however, we conclude that in towhees fecal-sac ingestion functions as a mechanism either to supplement parental metabolic needs or to suppress hunger so that parents can maintain high rates of feeding young.

\section{ACKNOWLEDGMENTS}

Financial support for our research came from a grant from the U.S. Fish and Wildlife Service (Cooperative Agreement 13420-01-J145) to MTM, a Frank M. Chapman Award from the American Museum of Natural History, and an American Ornithologists' Union Student Research Award to SBS. Our research was also funded in part by the United States Environmental Protection Agency (EPA) under a Greater Research Opportunities (GRO) Graduate Program award to SBS. EPA has not officially endorsed this publication, and the views expressed herein may not reflect the views of the EPA. We also acknowledge the able assistance of field assistants, including Michelle Campbell-Breckon, Jina Sager, John Deshler, and Nathan Einbinder, and reviews of the manuscript by Elena Berg, Luis Ruedas, Lucas J. Redmond, Amy Shipley, and two anonymous individuals. We thank the city of Portland and Lake Oswego for providing permits to work in the parks.

\section{LITERATURE CITED}

Analytical Software. 2003. Statistix 8.0. Analytical Software, Tallahassee, FL.

BARBOUR, R. W. 1950. Growth and feather development of towhee nestlings. American Midland Naturalist 44:742-749.
Blair, R. H., AND B. W. TuCKer. 1941. Nest sanitation. British Birds 34:206-215, 226-235, 250-255.

BlANCHER, P. J., AND R. J. ROBERTSON. 1987. Effect of food supply on the breeding biology of Western Kingbirds. Ecology 68:723-732.

Dell'Omo, G., E. Alleva, and C. CARERE 1998. Parental recycling of nestling faeces in the Common Swift. Animal Behaviour 56:631-637.

DunN, E. H. 1976. The relationship between brood size and age of effective homeothermy in nestling House Wrens. Wilson Bulletin 88:478-482.

DYER, B. D. 1998. A hypothesis about the significance of symbionts as a source of protein in the evolution of eusocial mole rats. Symbiosis 24:369-384

Grant, P. R., B. R. Grant, L. F. Keller, and K. Petren. 2000 Effects of El Niño events on Darwin's finch productivity. Ecology 81:2442-2457.

Greenlaw, J. S. 1996. Spotted Towhee (Pipilo maculatus), no 263. In A. Poole and F. Gill [EDS.], The birds of North America. Academy of Natural Sciences, Philadelphia.

HERrick, F. H. 1900. Care of nest and young. Auk 17:100-103.

Hurd, P. L., P. J. Weatherhead, and S. B. McRae. 1991. Parental consumption of nestling feces: Good food or sound economics? Behavioral Ecology 2:69-76.

Kenagy, G. J., C. Veloso, And F. Bozinovic. 1999. Daily food rhythms of food intake and feces reingestion in the degu, an herbivorous Chilean rodent: optimizing digestion through coprophagy. Physiological and Biochemical Zoology 72:78-86.

Lang, J. D., C. A. Straight, AND P. A. Gowaty. 2002. Observations of fecal sac disposal by Eastern Bluebirds. Condor 104:205-207.

Lombardo, M. P. 2008. Access to mutualistic endosymbiotic microbes: an underappreciated benefit of group living. Behavioral Ecology and Sociobiology 62:479-497.

McGowan, K. J. 1995. A test of whether economy or nutrition determines fecal sac ingestion in nesting corvids. Condor 97:50-56.

MCKAY, J. E. 2008. An analysis of parental care in Spotted Towhee populations located in urban greenspaces. M.Sc. thesis, Portland State University, Portland, OR.

MøLlER, A. P. 1993. Ectoparasites increase the cost of reproduction in their hosts. Journal of Animal Ecology 62:309-322.

Morton, M. L. 1979. Fecal sac ingestion in the Mountain Whitecrowned Sparrow. Condor 81:72-77.

MurPHY, M. T. 1986. Temporal components of reproductive variability in Eastern Kingbirds (Tyrannus tyrannus). Ecology 67:1483-1492.

Petit, K. E., L. J. Petit, And D. R. Petit. 1989. Fecal sac removal: do the pattern and distance of dispersal affect the chance of nest predation. Condor 91:479-482.

Pyle, P. 1997. Identification guide to North American birds: part 1. Slate Creek Press, Bolinas, CA.

RickleFs, R. E., AND J. M. STARCK, J. 1998. The evolution of the development mode in birds, p. 366-380. In J. M. Starck and R. E. Ricklefs [EDS.], Avian growth and development. Oxford University Press, Oxford, UK.

SPENCER, K. A. 2005. The effects of body state on nest sanitation and provisioning effort in breeding Barn Swallows (Hirundo rustica). Canadian Journal of Zoology 83:1360-1364.

SPSS. 2002. SPSS 11.5. SPSS, Inc., Chicago.

Stake, M. M., And P. M. CAVANAUGH. 2001. Removal of host nestlings and fecal sacs by Brown-headed Cowbirds. Wilson Bulletin 113:456-459.

TANAKA, L. K., AND S. K. TANAKA. 1982. Rainfall and seasonal changes in arthropod abundance on a tropical oceanic island. Biotropica 14:114-123.

TuCKER, B. W. 1942. Further data on nest-sanitation. British Birds 35:66-70, 72-97.

Weatherhead, P. J. 1984. Fecal sac removal by Tree Swallows: the cost of cleanliness. Condor 86:187-191. 